\title{
Introduction to Tractate Megillah
}

The name of the Tractate refers to the Esther scroll which is read connected to the festivities of Purim, but not necessarily on Purim. As a popular festivity, rejected by Sadducees, the celebration is justified in Pharisaic tradition by equating the Esther scroll with the Torah. This is aided by the fact that the Esther scroll is totally profane and therefore the general rule does not apply that Hagiographa and Prophets cannot serve as sources of religious rules, only as evidence of religious practices. The ninth Chapter of Esther therefore is analyzed as if it were a pentateuchal text. This can be qualified as anti-Sadducee demonstration.

The first part of the first Chapter discusses the dates of the reading under different circumstances; the festivities themselves are fixed on the $15^{\text {th }}$ of Adar for fortified ancient places and the $14^{\text {th }}$ for every other place. Since "Adar" in an intercalary year is repeated, this section is concluded with an enumeration of the differences regarding Purim between first and second Adar in such a year. The second part of the Chapter then is devoted to enumerations of differences in and extended discussion of the rules for related subjects, such as Sabbath and Holidays, different categories of vows, etc. Halakhot 1:2-5 contain some discussion of the computed calendar; Halakhah 1:11 mentions the Torah written in paleo-Hebrew script.

The second Chapter concentrates on the rules of the actual reading of the scroll and the weekly portions from the Pentateuch. The third Chapter brings the rules of synagogue buildings, synagogue services, and synagogue readings. The last Chapter then continues the rules of Torah and ancillary synagogue readings, with an appendix detailing the rules for tefillin and mezuzzot. The editor of the Venice editio princeps here invented a rule, proclaimed to originate in Moses's teachings on Mount Sinai, that the boxes of tefillin have to be black, while in both Talmudim the only rules are that the boxes be "square", i. e. cubes, and the straps black. 